\title{
Attributing and quantifying carbon monoxide sources affecting the Eastern Mediterranean: a combined satellite, modelling, and synoptic analysis study
}

\author{
R. Drori ${ }^{1}$, U. Dayan ${ }^{1}$, D. P. Edwards ${ }^{2}$, L. K. Emmons ${ }^{2}$, and C. Erlick ${ }^{3}$ \\ ${ }^{1}$ Department of Geography, The Hebrew University of Jerusalem, Jerusalem, Israel \\ ${ }^{2}$ National Center for Atmospheric Research, Boulder, CO, USA \\ ${ }^{3}$ Fredy and Nadinne Herrmann Institute of Earth Sciences, The Hebrew University of Jerusalem, Jerusalem, Israel
}

Correspondence to: R. Drori (ron.drori@mail.huji.ac.il)

Received: 29 October 2010 - Published in Atmos. Chem. Phys. Discuss.: 21 December 2010

Revised: 28 December 2011 - Accepted: 2 January 2012 - Published: 25 January 2012

\begin{abstract}
Pollutants from global sources are known to affect the Eastern Mediterranean Shore (EMS). However, there has been no previous study explicitly locating the European sources, characterizing their transport pathways, and quantifying their contribution to local concentrations in the EMS. In the current study, spatially tagged carbon monoxide was used as a tracer for pollutant transport from Europe to the EMS over five consecutive years (2003-2007) using the global chemical transport model MOZART-4. The model results were compared against NOAA/GMD ground station data and remotely sensed data from the Terra/MOPITT satellite and found to agree well on monthly basis but do not agree on daily basis. On synoptic scale, there is agreement between MOZART and GMD during July to August. A budget analysis reveals the role of $\mathrm{CO}$ from hydrocarbon oxidation on $\mathrm{CO}$ concentration during summer. European anthropogenic emissions were found to significantly influence EM surface concentrations, while European biomass burning (BB) emissions were found to have only a small impact on EM surface concentrations. Over the five simulated years, only two European biomass burning episodes contributed more than $10 \mathrm{ppb}$ to surface $\mathrm{CO}$ concentrations in the EM. $\mathrm{CO}$ enhancement in the EM during the summer was attributed to synoptic conditions prone to favorable transport from Turkey and Eastern Europe towards the EM rather than increased emissions. We attribute the apparently misleading association between $\mathrm{CO}$ emitted from European $\mathrm{BB}$ and $\mathrm{CO}$ enhancements over the EM to typical summer synoptic conditions caused by the lingering of an anticyclone positioned over the Western and Central Mediterranean Basin that lead to forest fires in the area. Combined with a barometric trough over the eastern
\end{abstract}

part of the Mediterranean Basin, this generates a prevailing transport of air masses from Eastern Europe to the EMS. Synoptic scale variations are shown to change the transport pathways from Europe towards the EMS having an overall small affect. CO concentration over the EMS can be describe as having 3 components: the seasonal cycle, the cycle of $\mathrm{CO}$ produced from hydrocarbon oxidation and a synoptic variation.

\section{Introduction}

Gas phase pollution from global and European sources is known to travel over the Mediterranean Sea downwind to the Eastern Mediterranean Shore (EMS), defined here as Israel, Lebanon and Syria (Lelieveld, et al., 2002; Kallos et al., 2007; Astitha et al., 2008; Luria et al., 1996; Wanger et al., 2000; Matvev et al., 2002; Duncan and Bay, 2004; Dayan and Levy, 2005; Erel et al., 2007). Evidence for contamination of lower tropospheric layers over the EMS by pollution emitted from European sources during summer has been shown (Stohl et al., 2002; Dayan and Levy, 2005; Dayan et al., 2002; Erel et al., 2007). However, locating the sources affecting the EMS, quantifying their contributions to local concentrations and characterizing the influence of synoptic pressure systems on short term variation have not yet been accomplished. Furthermore, it should be noticed that the EMS does not always share the same transport pathways of other parts of eastern Mediterranean region (e.g. Greece).

In this study, we use carbon monoxide (CO) as a tracer for pollutants. CO has a global-average lifetime of about two 
Table 1. GMD stations.

\begin{tabular}{llllll}
\hline Code & Name & Latitude & Longitude & Elevation $(\mathrm{m})$ & Country \\
\hline WIS & WIS Station Negev Desert & 31.13 & 34.88 & 400.0 & Israel \\
HUN & Hegyhatsal & 46.95 & 16.65 & 248.0 & Hungary \\
LMP & Lampedusa & 35.52 & 12.62 & 45.0 & Italy \\
BSC & Black Sea Constanta & 44.17 & 28.68 & 3.0 & Romania \\
OXK & Ochsenkopf & 50.03 & 11.80 & 1022.0 & Germany \\
BAL & Baltic Sea & 55.35 & 17.22 & 3.0 & Poland \\
MHD & Mace Head County Galway & 53.33 & -9.90 & 5.0 & Ireland \\
\hline
\end{tabular}

months and its molecular weight is close to that of air. It is widely used as a tracer to track pollution transport. In addition to chemical oxidation in the atmosphere, $\mathrm{CO}$ is emitted from anthropogenic sources, biomass burning (BB), vegetation and ocean. The $\mathrm{CO}$ seasonal cycle is mainly governed by the concentration of the hydroxyl radical $(\mathrm{OH})$ in the troposphere (Novelli et al., 1992) and is expected to be lowest in the late summer when photochemistry is active and highest during late winter or spring.

$\mathrm{CO}$ concentration in a specific location depends on several processes such as emissions, chemical production, chemical loss, transport and deposition, and these are associated with different spatial and temporal scales. The goal of this research is twofold: investigate CO sources affecting the EMS at both large spatial and temporal scales and synoptic scales. From large scale perspective our aim is to locate and quantify the contribution of CO sources to local EMS concentration and to assess the relative importance of the various source types. From synoptic scale perspective we are concerned with the question of how synoptic scale processes influence the short term $\mathrm{CO}$ variation and to what extent synoptic pressure systems can explain synoptic scale variation.

The paper is organized as follows: First, to gain basic knowledge on the temporal and spatial behavior of $\mathrm{CO}$ over the research domain, measurements - both in situ (Sect. 2) and remotely sensed (Sect. 3) - are shown and analyzed. In Sect. 4 we will introduce the MOZART-4 model, the emissions inventory used and a brief description of the concept of tagged runs. In Sect. 5 the model results are evaluated against measurements. The model results used for budget analysis and to locate the sources affecting the EMS along with the contribution of each source to local concentrations are discussed in Sect. 6. In the following Sect. 7 the relative importance of anthropogenic sources and BB sources are analyzed. In Sect. 8 the the influence of synoptic systems on synoptic scale variation is examined and discussed, followed by the last Sect. 9 including summary and main conclusions.

\section{In-situ flask measurements over Sde-Boker}

The only background monitoring ground station located at southern Israel is available over the whole EMS region. CO concentration is measured on a near weekly basis at SdeBoker $\left(31.13^{\circ} \mathrm{N}, 34.88^{\circ} \mathrm{E}, 400 \mathrm{~m}\right)$ as part of the NOAA Earth System Research Laboratory Global Monitoring Division (NOAA/GMD) flask sampling program (Novelli et al., 1992, 1998, 2010) and is operated by the Weizmann Institute of Science (WIS). The site is located far from urban centers and therefore is well-suited for background measurements. CO monthly means for Sde-Boker along with other European GMD stations (see Table 1) are shown in Fig. 1 (solid red line for WIS, dashes lines for other European stations).

Three main features are evident:

1. The CO seasonal cycle: high over winter months, decreasing sharply during April and increasing again from November.

2. In contrast to the seasonal cycle, higher CO concentrations are observed during August compared to July and September.

3. The minimum average CO is seen in September, which is later than other stations except LMP.

While two other stations share a similar pattern (OXK and $\mathrm{BSC}$ ), this feature is seen earlier at WIS (August) than the two other stations (September).

A closer look at the anomalous high CO during August reveals a more complicated picture. Measurements during June to October can be partitioned, on yearly basis, to 3 categories:

1. "Regular" seasonal cycle (years 2005)

2. Local maxima during August (years: 2001, 2002, 2003, 2004, 2006, 2007, 2008).

3. Local maxima during July (year 2000).

\section{MOPITT measurements.}

The flask measurements described in the previous section provide an accurate measure of $\mathrm{CO}$ concentration at a specific point but contain no information about the spatial variability of $\mathrm{CO}$ over the region. To characterize $\mathrm{CO}$ spatial variability satellite measurements can be used. 


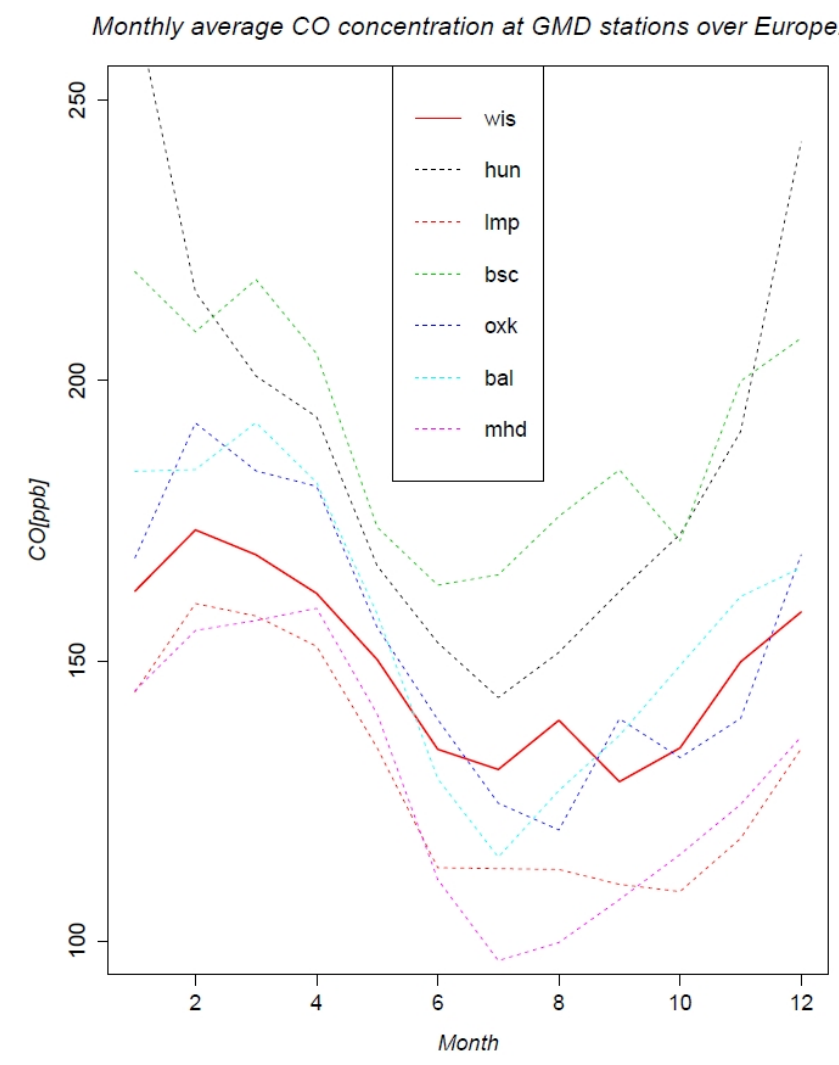

Fig. 1. CO monthly means for Sde-Boker $\left(31.13^{\circ} \mathrm{N}, 34.88^{\circ} \mathrm{E}\right.$, $400 \mathrm{~m}$ ) along with other European GMD stations (solid red line for WIS, dashes lines for other European stations).

\subsection{MOPITT instrument and retrieval.}

Measurements Of Pollution In The Troposphere (MOPITT), onboard the Terra satellite, is an eight-channel gas correlation radiometer with pixel resolution of about $22 \mathrm{~km}$ by $22 \mathrm{~km}$ at nadir and a swath width of about $640 \mathrm{~km}$. Global coverage is achieved in about three days under clear sky conditions. Version 4 MOPITT level $2 \mathrm{CO}$ retrievals are used in this study (Deeter et al., 2010). The MOPITT retrievals include the $\mathrm{CO}$ mixing ratio for ten atmospheric levels from the surface to $100 \mathrm{hPa}$ with $100-\mathrm{hPa}$ grid spacing and the total column amount of $\mathrm{CO}$ in the atmosphere. MOPITT retrievals are based on the Maximum A Posteriori (MAP) technique incorporating a priori information about the $\mathrm{CO}$ concentrations profile and its covariance. A full description of the retrieval method can be found at Deeter et al. (2003) and Deeter et al. (2010).

\subsection{Evaluating MOPITT sensitivity to the lower troposphere near Sde-Boker}

Here we are interested in $\mathrm{CO}$ concentration at the lower troposphere (LT) and therefore MOPITT sensitivity to this layer should be examined before using the retrievals.
MOPITT measurements rely on thermal contrast between the surface and atmosphere and therefore, in common with other operational remote sensing measurements of $\mathrm{CO}$, are mainly sensitive to the free troposphere with only limited surface sensitivity (Edwards et al., 2004; Worden et al., 2010). The thermal contrast depends on surface type, vegetation and solar illumination. Over the sea, the skin temperature is very close to the air temperature and therefore we expect a low sensitivity of MOPITT retrieval to the LT. Over arid area (such as Sde-Boker), especially during summer, skin surface temperature can be much higher than the air temperature leading to a high thermal contrast and a better sensitivity to the LT. There are additional factors determining MOPITT sensitivity such as: $\mathrm{CO}$ loading and $\mathrm{H}_{2} \mathrm{O}$ vertical profile, thus even under high thermal contrast the retrieval sensitivity might be low.

A quantitative measure of MOPITT vertical sensitivity can be gained from the averaging kernel matrix. MOPITT retrieved state vector $\hat{\boldsymbol{x}}$ can be expressed as a weighted average of the true state vector $\boldsymbol{x}$ and the apriori state vector $\boldsymbol{x}_{\mathrm{a}}$ with the following relation (Deeter et al., 2010):

$\hat{\mathbf{x}} \approx \mathbf{A K} \boldsymbol{x}+(\mathbf{I}-\mathbf{A K}) \boldsymbol{x}_{\mathrm{a}}$

Where $\mathbf{A K}$ is the averaging kernel matrix and $\mathbf{I}$ is the identity matrix. For MOPITT v4 these quantities are defined in terms of $\log (\mathrm{VMR})$ (Deeter et al., 2010).

The averaging kernel matrix, which indicates the sensitivity of the retrieved state vector to the true state vector, can be written as:

$\mathbf{A K}=\frac{\partial \hat{\mathbf{x}}}{\partial \boldsymbol{x}}$

Each row of the AK matrix describes how all of the elements in the true state vector contribute to a particular element of the retrieved state vector (Deeter et al 2003).

Examining the shape of the $\mathbf{A K}$ for a specific level (e.g. the corresponding row) will reveal the vertical resolution and sensitivity of the retrieval. The AK not necessarily peaks at their corresponding pressure level and in most cases are not sharply defined meaning the retrieval can be interpreted as an averaged valued over several layers. To illustrate this Fig. 2 shows the AK of two retrievals near GMD/ESRL SdeBoker located at the Negev desert. During day (right panel) the $900 \mathrm{mb}$ curve peeks in the $900 \mathrm{mb}$ level, meaning the retrieval is significantly based on information from measurements rather than apriori data. This peak is probably due to the high thermal contrast, as expected for this hot and arid area. It is important to notice that the $900 \mathrm{mb}$ retrieval is sensitive to several other layers (from $1000 \mathrm{mb}$ to $700 \mathrm{mb}$ ) and therefore will represent a weighted average value of these layers. Another important point is that the $900 \mathrm{mb}$ retrieval is more sensitive to the surface than the surface retrieval. During night (left panel) the AK peek at $900 \mathrm{mb}$ is less pronounced and comparable to the $800 \mathrm{mb}$ curve. This is again probably due to reduced thermal contrast between surface 

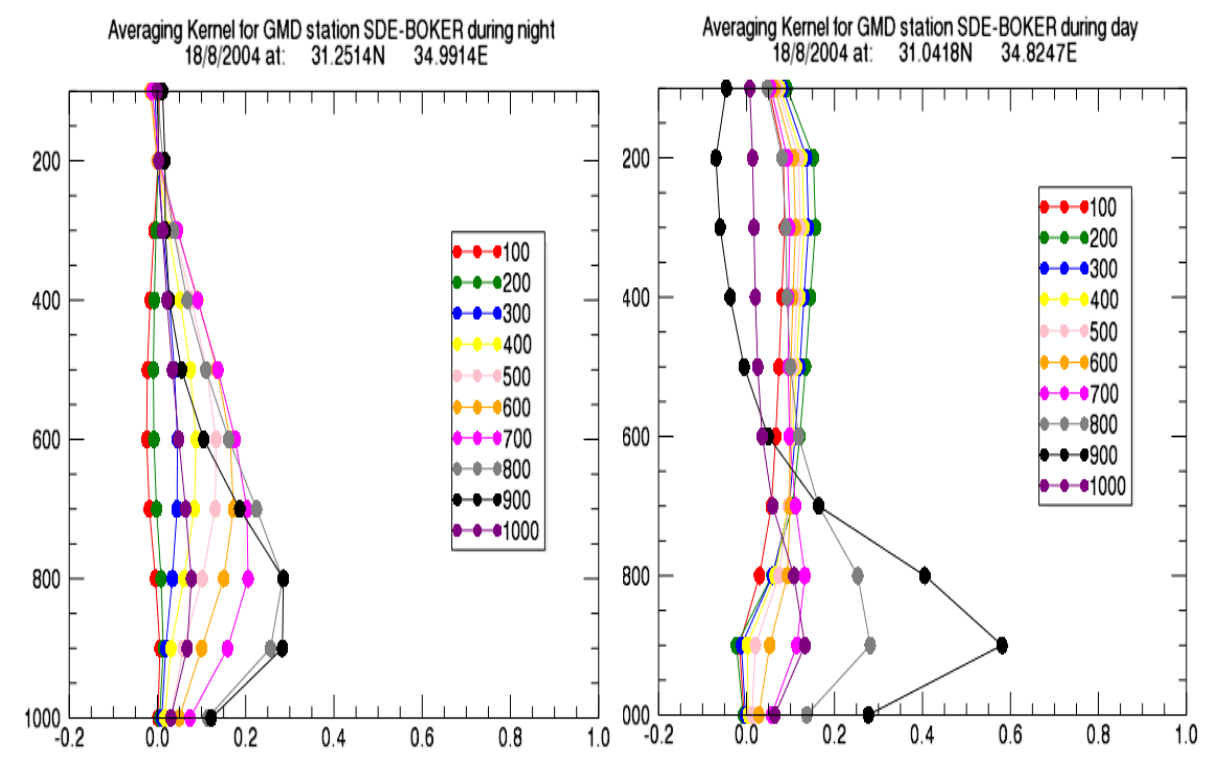

Fig. 2. Averaging kernels obtained near SDE-BOKER GMD station during 18/08/2004. During day (left panel) the $900 \mathrm{mb}$ retrieval sharply peaks at the same level, meaning there is a good sensitivity to lower tropospheric concentration. During night (right panel) the $900 \mathrm{mb}$ retrieval moderately peaks at its level with same contribution from the $800 \mathrm{mb}$ level indicating slightly less sensitivity to the lower tropospheric concentration.

temperature and the layers above, which is less over night. The shapes of the $800 \mathrm{mb}$ and $900 \mathrm{mb}$ are very similar indicating a high correlation for the retrieved values at these levels.

In addition, the "Degrees of Freedom for Signal" (DFS), which is the trace of the AK matrix, can be calculated. DFS is a measure of the number of components of the retrieved $\mathrm{CO}$ profiles that are not constrained by the a priori. (Deeter et al., 2003). A low DFS value indicates that the retrieval is mainly based on a priori data and not on measurement. The range of DFS values associated with MOPITT thermal infrared retrievals span between 0.5 and 2 (Deeter et al., 2004). DFS values over the EMS are relatively high and span between 1 and 2. Worden et al. (2010) defined the surface DFS, as a measure of MOPITT LT sensitivity. The surface DFS equals to the sum of the AK diagonal elements from the surface to $800 \mathrm{hPa}$. Retrievals with surface DFS $>0.4$ are defined as sensitive to the LT (Worden et al., 2010). Figure 3 show the monthly average surface DFS near Sde-Boker ( $\pm 1 \mathrm{deg}$, land only). During day (red dots) the surface DFS is higher than 0.4 from March to October and is much higher than the global average which is 0.25 (Worden et al., 2010). During nights the surface DFS is low as excepted (surface DFS $<0.2$ ). Figure 3 presents the Monthly average $\mathrm{CO}$ at $900 \mathrm{mb}$ (red dots) along with their standard deviation (dashes bars). Only retrievals with surface DFS higher than 0.4 were used. The seasonal cycle can be clearly seen, but the anomalous high during August cannot be seen (Except for summer 2006). A possible explanation for this is that MOPITT retrievals differ fundamentally from in-situ measurements.
While in-situ measurements represent a small volume at a specific layer, MOPITT retrievals can be seen as averaged value over several layers (e.g. the $900 \mathrm{mb}$ retrieval is average from the surface up to the $700 \mathrm{mb}$, see Eq. 1).

The anomalous high concentration during August might be restricted to lower levels, and therefore averaging over several layers might mask this signal. MOPITT retrievals are highly variable both spatially and temporally (as described by the dashed bars), especially during winter and spring. This variability is associated with cold fronts during winter and the highly variable boundary layer height $\left(300-2000 \mathrm{~m}^{2}\right)$ during spring. Points without bars (e.g. December), denote a single measurement due to low retrieval sensitive to the LT (surface DFS <0.4).

\section{Model description}

\subsection{MOZART-4}

The Model for Ozone and Related chemical Tracers, version 4 (MOZART-4) is a global chemical transport model of the troposphere (Emmons et al., 2010). For this study, the tracer version of MOZART-4 is used, where only CO is simulated. $\mathrm{CO}$ sources include direct emissions and secondary production from the oxidation of hydrocarbons, while CO sinks include reaction with $\mathrm{OH}$ and dry deposition. Monthly averages of $\mathrm{OH}$ and $\mathrm{CO}$ chemical production fields (from $\mathrm{CH}_{4}$ and other hydrocarbon oxidation) are taken from a previous simulation with full chemistry. The dry deposition scheme from Sanderson et al. (2003) is included in MOZART-4. 
Table 2. Tag definition.

\begin{tabular}{llllll}
\hline Tag id & Name & Min Lat & Max Lat & Min Lon & Max Lon \\
\hline 1 & South Western Europe & 36 & 50 & -10 & 10 \\
2 & Balkans & 36 & 50 & 10 & 30 \\
3 & Turkey and Eastern Europe & 36 & 50 & 30 & 45 \\
4 & North Western Europe & 50 & 60 & -10 & 30 \\
5 & North Eastern Europe & 50 & 60 & 30 & 45 \\
6 & EMS & 30 & 36 & 30 & 36 \\
\hline
\end{tabular}
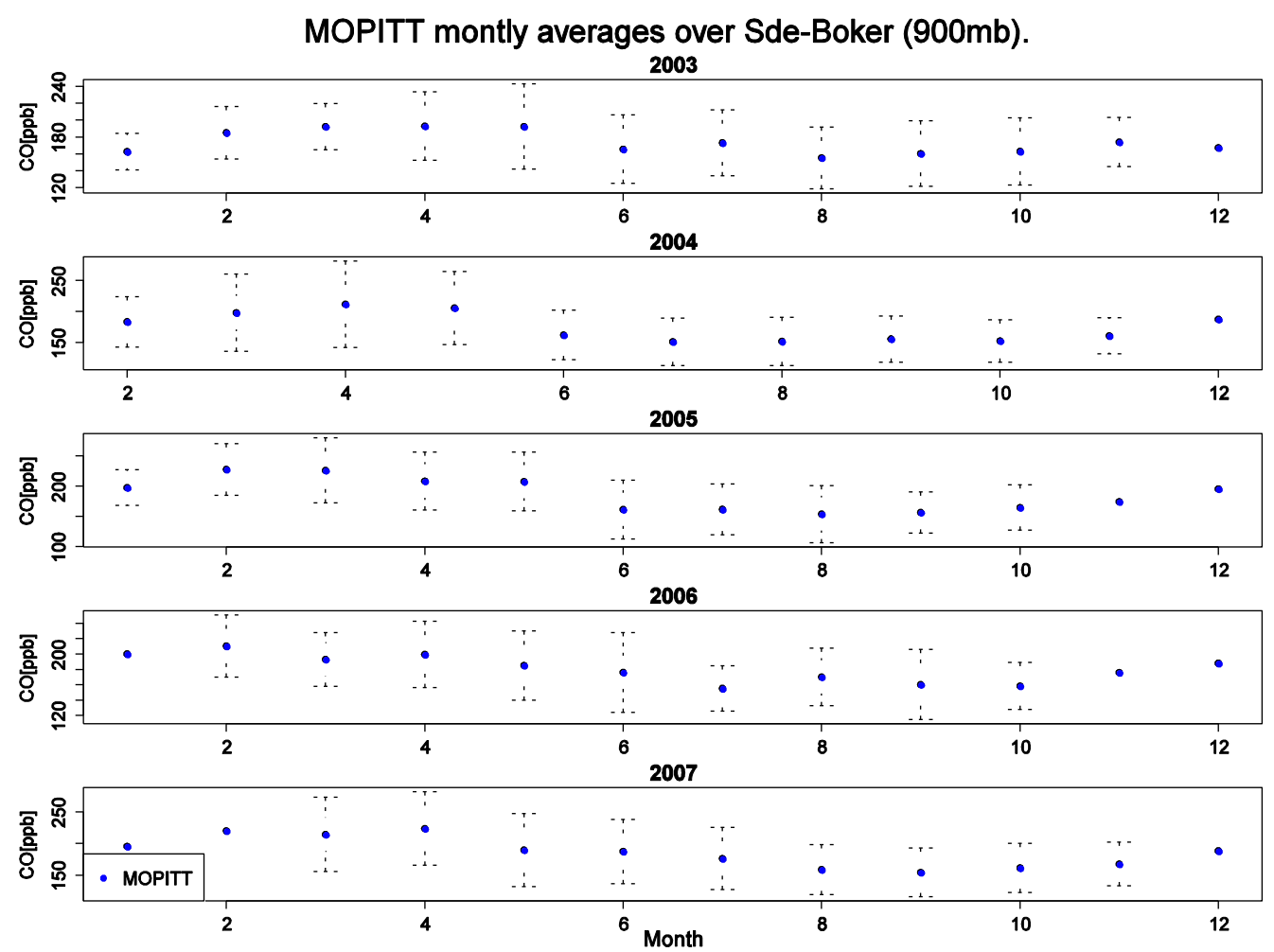

Fig. 3. Monthly average CO from MOPITT retrievals (blue dot) along with their standard deviation (dashed lines). Retrievals with surface DFS $<0.4$ where filtered out.

The model is driven by meteorological inputs from the $\mathrm{Na}$ tional Centers for Environmental Prediction/National Center for Atmospheric Research NCEP/NCAR Reanalysis with time steps of $6 \mathrm{~h}$ (Kalnay et al., 1996). A horizontal resolution of $2.8^{\circ}$ in latitude by $2.8^{\circ}$ in longitude is used with 28 sigma levels extending from the surface up to a pressure level of about $2 \mathrm{hPa}$. The model is run in time steps of $20 \mathrm{~min}$.

\subsection{CO emissions}

Anthropogenic pollutants are emitted principally from fixed sources, such as urban or industrial areas, or from specific known locations, such as roads. Although there is evidence that European anthropogenic emissions (Meszaros et al., 2005) may be decreasing, we assumed a constant an- nual anthropogenic surface emission flux of $\mathrm{CO}$, using the values for the year 2000 as obtained from the Precursors of Ozone and their Effects in the Troposphere (POET) inventory (Granier et al., 2005).

BB emissions, on the other hand, exhibit large spatial and temporal variability (Edwards et al, 2004) and are characterized by large uncertainties in timing, location, and magnitude (Bian et al., 2007). Furthermore, synoptic scale transport is very sensitive to the timing and location of emissions (Ranmar et al., 2002; Dayan and Levy, 2002, 2005; Dayan and Lamb, 2007). Chen et al. (2009) applied three BB inventories with different temporal resolutions: monthly from Global Fire Emissions Database version 2 (GFEDv2), 8-day (GFEDv2 resampled with MODIS 8-day fire counts), and daily (GFED 8-daily resampled using the GOES ABBA 


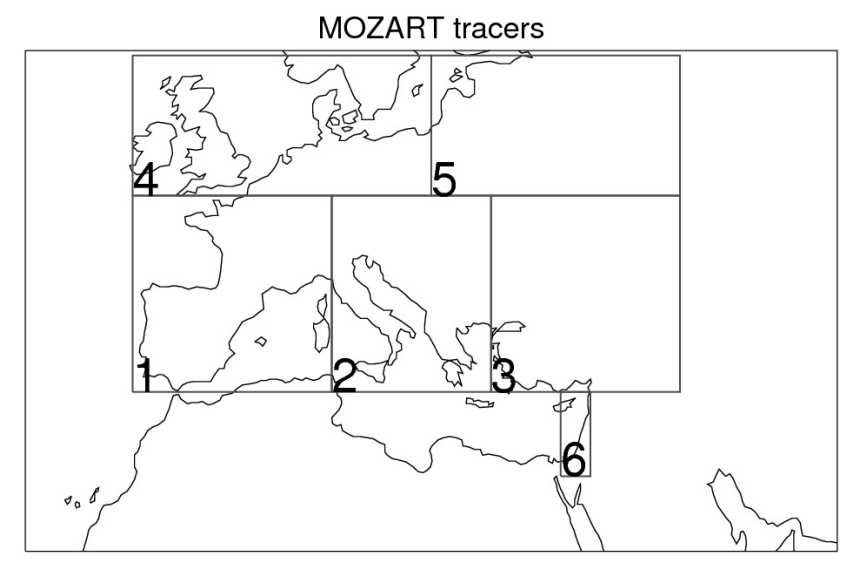

Fig. 4. Spatially tagged CO regions (both anthropogenic and BB) that were used for tracing transport in MOZART. The partitioning is based on previously known transport patterns and the emission inventory.

diurnal cycle). They compared the model results with satellite, aircraft, and ground based measurements and concluded that, "switching from monthly to 8-day time intervals for emissions has the largest effect on $\mathrm{CO}$ and aerosol distributions, and shows better agreement with measured day-today variability". In the absence of a daily inventory, we used the 8-day fire emissions from the Global Fire Emissions Database version 2 (van derWerf et al., 2006). This inventory was resampled from the monthly GFED 2 inventory to an 8day time step using Moderate Resolution Imaging Spectroradiometer (MODIS) fire hot spots (Giglio et al., 2003).

\subsection{The concept of tagged runs}

$\mathrm{CO}$ has a principal chemical sink, the $\mathrm{OH}$ radical, and therefore can be simulated linearly. CO sources can be tagged according to their type (e.g., anthropogenic or BB), location (e.g., east or west Europe), and timing (e.g., month of the emissions). Each of these tagged $\mathrm{CO}$ sources is treated as a separate "species" and can be used as a tracer to identify transport pathways and to evaluate the contribution of each source to local CO total concentration. Here we spatially tag the European CO sources and separate them into two types, $\mathrm{BB}$ and anthropogenic sources. For each source type, six areas ("tags") are defined, making a total of 12 tags for the whole continent. The six regions that were tagged for each source type are shown in Fig. 4 (see Table 2): South Western Europe (tag 1), Balkans (tag 2), Turkey and Eastern Europe (tag 3), North Western Europe (tag 4), North Eastern Europe (tag 5), and EMS (tag 6). The tags were defined according to known transport pathways (Erel et al., 2007; Dayan and Levy, 2005) and emission spatial distributions according to the POET and GFED inventories. The simulated mixing ratios of $\mathrm{CO}$ and each tag are averaged over $24 \mathrm{~h}$.
In addition $\mathrm{CO}$ from $\mathrm{CH}_{4}$ (Come) and $\mathrm{CO}$ from hydrocarbon oxidation $(\mathrm{COhc})$ is also included for budget analysis.

\section{Model results and evaluation}

\subsection{Model results}

The time series of CO surface concentration for a MOZART grid cell centered over $32.85^{\circ} \mathrm{N}$ and $33.75^{\circ} \mathrm{E}$ between 2003 and 2007 is shown in Fig. 5. The seasonal cycle can be seen, with high $\mathrm{CO}$ concentration during winter months, reaching a maximum in spring, and decreasing sharply around May. The $\mathrm{CO}$ concentration for the mid-summer months (i.e., July and August) is higher than in the early summer (i.e., MayJune). Another decrease in concentration can be seen in September and October followed by a sharp increase during November and December. A similar pattern is exhibited by the five year averaged $\mathrm{CO}$ (Fig. 6). CO variability during autumn, winter, and spring is much higher than in the summer, reflecting the synoptic variability during these months compared with the stable atmospheric conditions characterizing the summer.

\subsection{Comparison of the model to MOPITT Observations}

To properly evaluate MOZART with MOPITT products, the averaging kernel and a priori profile associated with each of the MOPITT retrievals must be applied to the model profiles (Emmons et al., 2009a). Using eq1 we can write this transformation as:

$$
\underset{\text { MOZART }}{\stackrel{\hat{X}}{X}}=X_{\mathrm{a}}+\mathbf{A K}\left(X_{\mathrm{MOZART}}-X_{a}\right)
$$

Where $\stackrel{\hat{X}}{\text { MOZART }}$ is the simulated retrieved profile base on the modeled profile $\left(X_{\text {MOZART }}\right)$ and MOPITT apriori data $\left(X_{\mathrm{a}}\right)$ and MOPITT AK. It is important to notice that the V4 state vector represents the CO profile as a set of log Volume Mixing Ratio (VMR) values and therefore the transformation (eq3) should be done in terms of $\log (\mathrm{VMR})$.

We evaluate MOZART results by applying eq3 for each of MOPITT retrieval over a specific MOZART cell and then averaging the "retrieved" MOZART and MOPITT for each day. As mentioned previously, MOPITT retrievals over water surface are less sensitive to the LT and therefore were filtered out and only retrievals with surface DFS $>0.4$ were used. Figure 7 shows a comparison between MOPITT and "retrieved" MOZART at $900 \mathrm{mb}$ level, on a monthly basis. While correlation is high $(0.67<R<0.88)$ there is a large bias ( $\sim 20$, less than $20 \%$ ). Emmons et al (2009) found a bias of $25 \%$ for MOPITT $700 \mathrm{mb}$ retrievals. While bias may be higher near surface, model shortcoming can also contribute to this high bias (e.g. emission inventory, too high $\mathrm{OH}$ concentration, error in boundary layer height). Using a lower surface DFS to filter MOPITT retrievals will lead to lower 

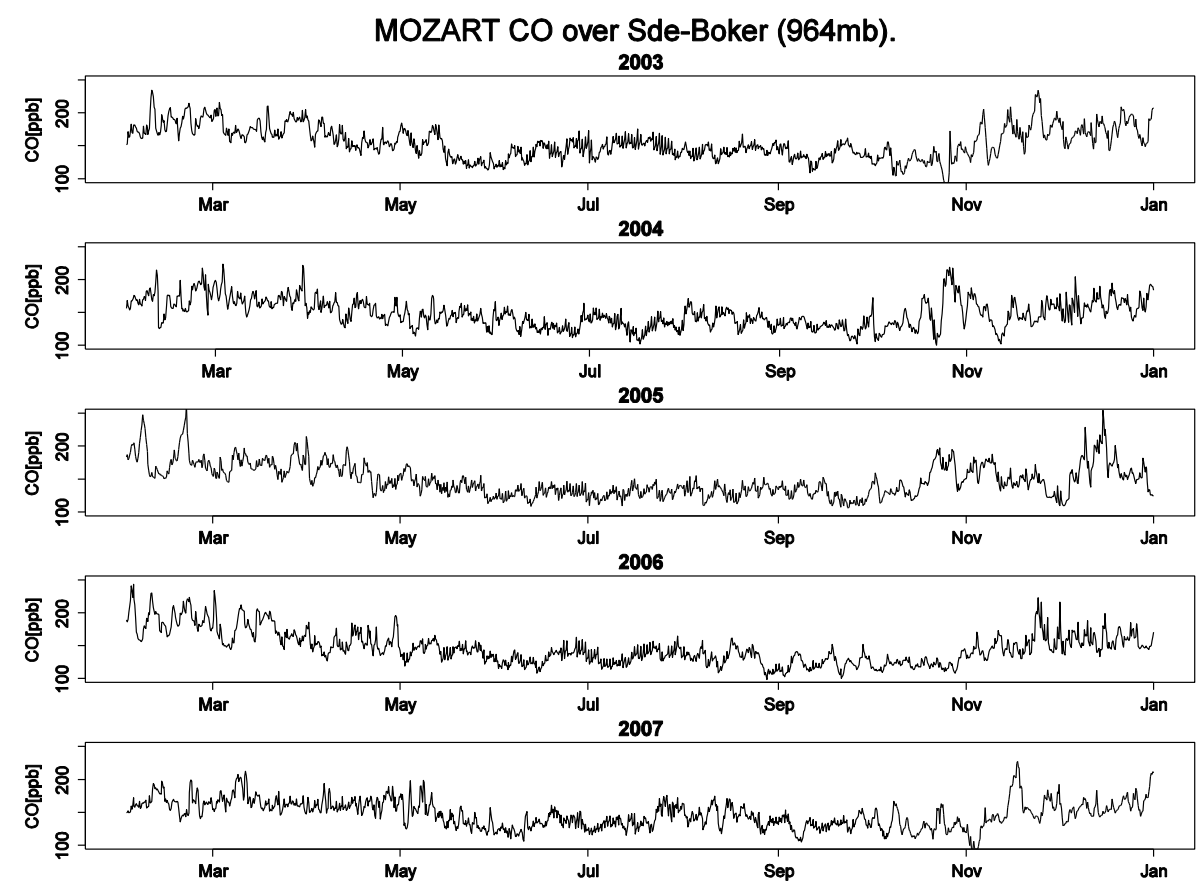

Fig. 5. MOZART-4 CO surface concentration (ppb) for the study period (2003-2007). The seasonal cycle, high CO from autumn to spring and low $\mathrm{CO}$ during summer, is clearly seen. $\mathrm{CO}$ variability from autumn to spring is much higher than during summer, reflecting the synoptic system variability during these months as opposed to the stable summer conditions.

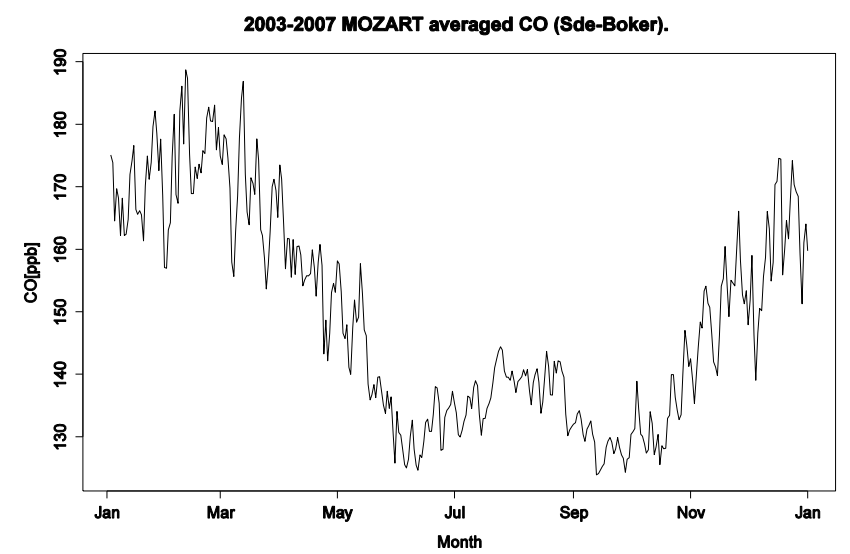

Fig. 6. Average $\mathrm{CO}$ surface concentrations (ppb) during the study period (2003-2007). A deviation from the expected seasonal cycle during summer can be seen.

correlation and lower bias, as the retrievals will be closer to the a priori, which is based on MOZART simulation climatology (see Eq. 3). Daily comparison between MOPITT and MOZART yields much lower correlation $(R \sim 0.5)$.

\subsection{Evaluation of the model with gmd ground station data}

A comparison of MOZART simulated CO concentrations (resampled to Sde-Boker pressure level using local meteorological station measurements) to the GMD station data from Sde-Boker (southern MOZART grid cell) is shown in Fig. 8. Model output is co-sampled with GMD measurements and averaged for each month. The model generally reproduces both the magnitude and variability of $\mathrm{CO}$ concentrations well, with an overall correlation ranging from 0.61 to 0.91 and bias ranging from $-5 \mathrm{ppb}$ to $12 \mathrm{ppb}$. As will be shown in the next section, this correlation is mainly due to the seasonal cycle and the model cannot reproduce the synoptic scale variability properly, unless for summer months. Higher bias can be seen during winter and spring months which are characterized by MOPITT as having higher spatial variability that could not be simulated by the coarse spatial resolution used for this simulation. During summer the bias is minimal (except for July 2007). The lower end of the correlation values and the higher end of the bias values come from the spring months (March-May) of 2003. A possible explanation for the discrepancy between the model and measurements in the spring of 2003 is the presence of widespread European forest fires that existed during that season and might not be properly quantified by the emission inventory. Fireinduced plume rise is not included in the simulations and might also have contributed to this bias. The correlation for 

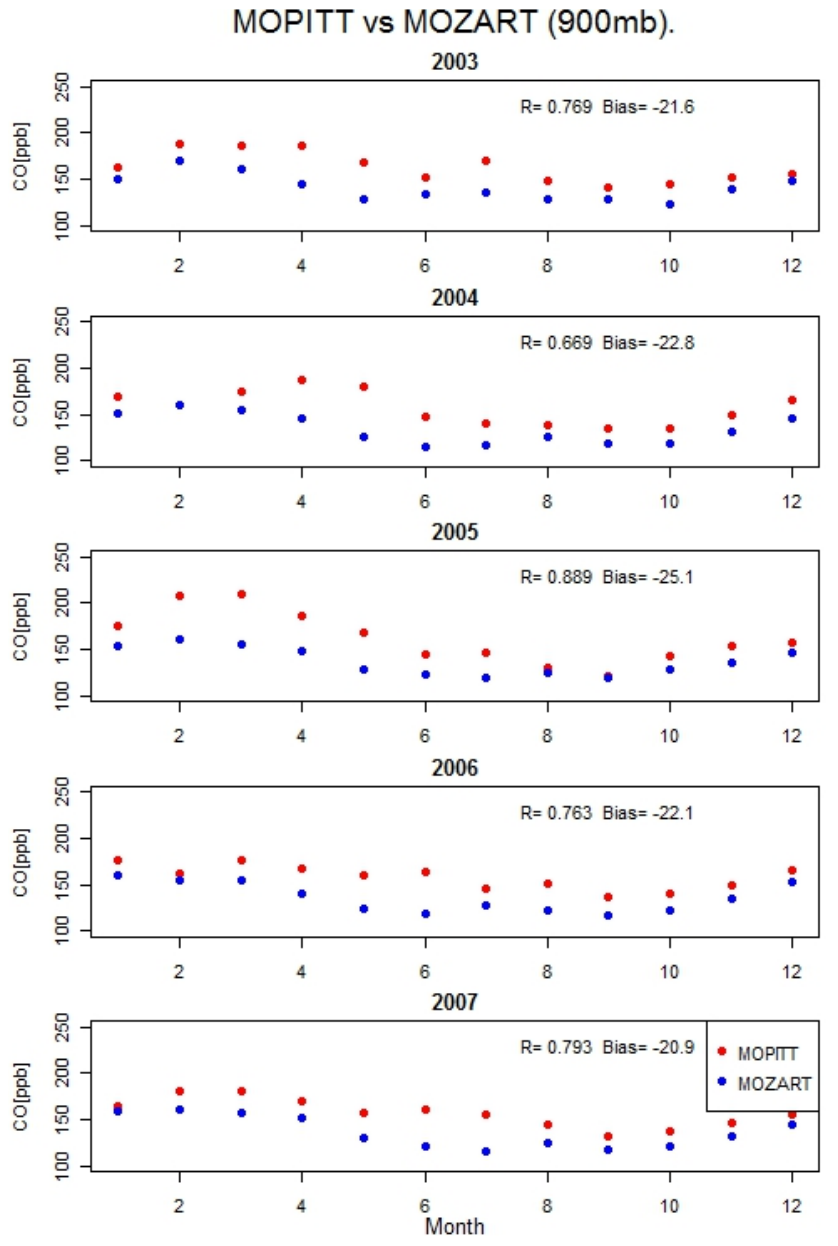

Fig. 7. Comparison of MOPITT V4 (blue dots) with MOZART (red dots) at $900 \mathrm{mb}$, for the study period (2003-2007). The MOZART-4 results have been transformed with the MOPITT averaging kernels and a priori data.

the years $2005-2007$ alone is relatively high, ranging from 0.73 to 0.91 .

\subsubsection{Evaluation of the Model ability to simulate synoptic scale variations}

Synoptic scale can be coarsely defined as having a temporal scale of several days. Here we will define the synoptic temporal scale, based on GMD sampling frequency, to be equal to a week.

To evaluate the model ability to reproduce the synoptic scale variation, MOZART results were conditionally co-sampled with GMD measurements at Sde-Boker and only measurements without any quality assurance flags (flag $=" . . . "$ ) were used. For each year, a polynomial fit was used to construct the seasonal cycle. The two time series were deseasonalized by subtracting $\mathrm{CO}$ concentration from the seasonal cycle. Figure 9 shows the deseasonalized time series for the years 2003-2007. Generally, the model is un-
MOZART vs GMD monthly averages (co-sampled). 2003
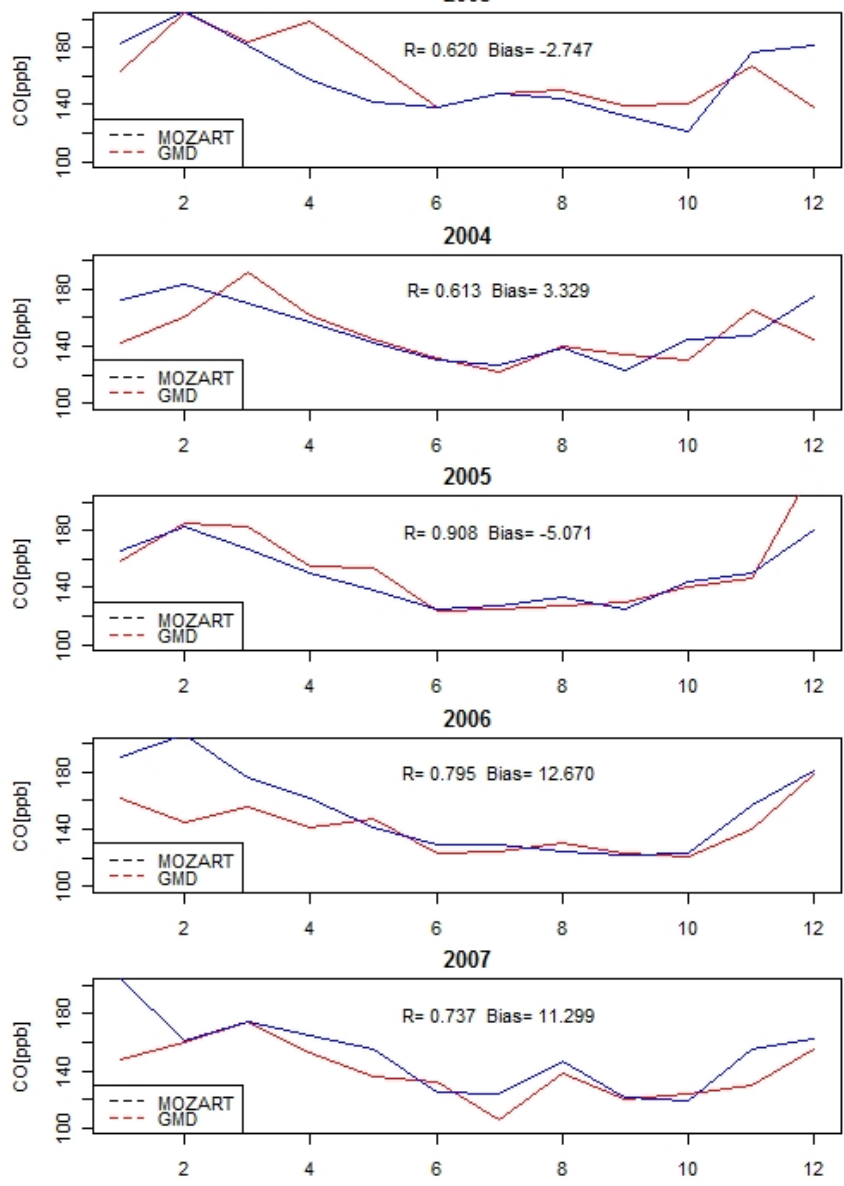

Fig. 8. Comparison of MOZART CO mixing ratio (at $964 \mathrm{hPa}$ ) with co-sampled GMD flask measurements at Sde-Boker $\left(31.13^{\circ} \mathrm{N}\right.$, $34.88^{\circ} \mathrm{E}, 400 \mathrm{~m}$ a.s.1.) for the study period (2003-2007).

able to reproduce the synoptic scale variation. The model was able reproduce the synoptic scale variation for years 2003-2007 for the period between July and September. Two possible reasons could lead to this good agreement:

1. Summer months over the EMS are characterized by stable atmosphere and small changes in synoptic pressure systems.

2. CO from hydrocarbon oxidation has a defined seasonal cycle (as will be shown in the next section) and the model is capturing this cycle.

\section{Conclusions}

On monthly basis, high correlation is seen between the model and measurements that have been used to evaluate the simulation. The model show a small bias compared to the Insitu ground measurements (GMD) and high bias compared 

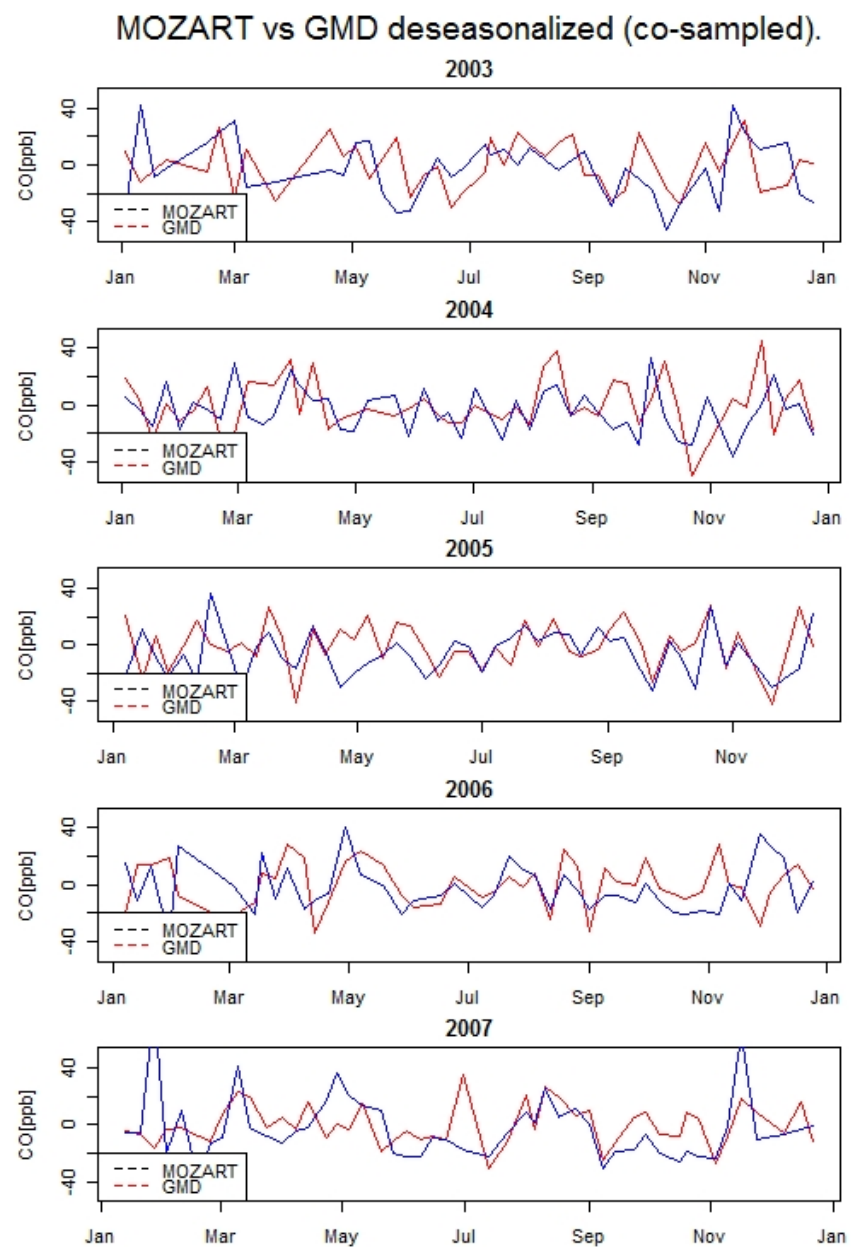

Fig. 9. A comparison between the deseasonalized time series of MOZART (blue) and GMD (red) for the years 2003-2007. The model was able to reproduce the synoptic scale variation for these years for the period between August to October.

to MOPITT retrievals. The model results correlates nicely $(0.61<R<0.91)$ with weekly GMD measurements, but have gain low correlation $(R \sim 0.5)$ where compared to daily MOPITT retrievals. These results imply that MOZART cannot simulate adequately daily variability during winter months. During summer months (August-October) the model can simulate well synoptic scale variation (with time scale of a week). The model can reproduce the synoptic scale variation for the period between July to September.

\section{Budget analysis}

\subsection{CO sources by type}

$\mathrm{CO}$ is released from many sources which differ in their magnitude, spatial and temporal variability. Transport and diffusion of $\mathrm{CO}$ in the atmosphere depends, among other factors, on these properties. Transport range, for example, relies much on the effective release height. Anthropogenic emissions are considered as surface sources whereas $\mathrm{CO}$ originated from hydrocarbon oxidation can be released at higher levels and the release of $\mathrm{CO}$ from biomass burning depends on the fire radiant heat. Therefore it would be desirable to investigate the contribution of these sources and their temporal variability. Since this research is focused on synoptic scale variation, of typical temporal scale of few days, it is essential to evaluate the synoptic scale variation associated with each source type.

$\mathrm{CO}$ sources can be categorized in several ways; in this study CO sources where partitioned into five types: anthropogenic, biogenic, fire, chemical production and ocean. For each one of these sources, a global tag was defined. Figure 10 shows MOZART simulation for two year (20062007) over the EM shore. CO concentration time series is shown for each source (for MOZART cell centered at $30^{\circ} \mathrm{N}$ and $33.75^{\circ} \mathrm{E}$ ). Biogenic sources (green line) and BB sources (red line) both have a minor contribution. Biogenic sources have a seasonal cycle with high contribution over winter and low daily variability. BB has no defined seasonal signature and contributes episodically. Except for August 2007, daily variation is small. $\mathrm{CO}$ from chemical production (orange) contributes substantially $(50-80 \mathrm{ppb})$ with defined seasonal cycle; low over winter and autumn and high during summer and have low daily variability. The main contributor to the total CO is the anthropogenic source (purple, 50-180 ppb). Its seasonal cycle is as expected, i.e., elevated concentration during winter decreasing during spring, slightly increasing during the summer; and decreasing again during the fall. The daily variability is high and similar to the total $\mathrm{CO}$ daily variability. Emission from the ocean is negligible (not shown). Comparing the daily variability of the various sources we can conclude that total $\mathrm{CO}$ daily variability is governed mainly by anthropogenic sources.

\subsection{European CO sources per region affecting the EMS region}

To further attribute the daily variation, the anthropogenic sources where spatially tagged. For each continent in the northern hemisphere, i.e., North America, Europe and Asia a tag was defined. Figure 11 shows the contribution of anthropogenic sources for each of these continents (not including Africa). European anthropogenic sources contribute substantially $(10-80 \mathrm{ppb})$ to local CO concentration with high daily variability all around the year. Asian and North American sources are in the same order of magnitude (10-25 ppb) with low daily variability during most of the year, and very small variability during summer. It is evident that during summer daily variation in $\mathrm{CO}$ concentration are mainly caused by European anthropogenic sources.

The seasonal cycle of the European contribution is very similar to the seasonal cycle of total $\mathrm{CO}$, with a high concentration in winter, spring, and autumn and a lower 


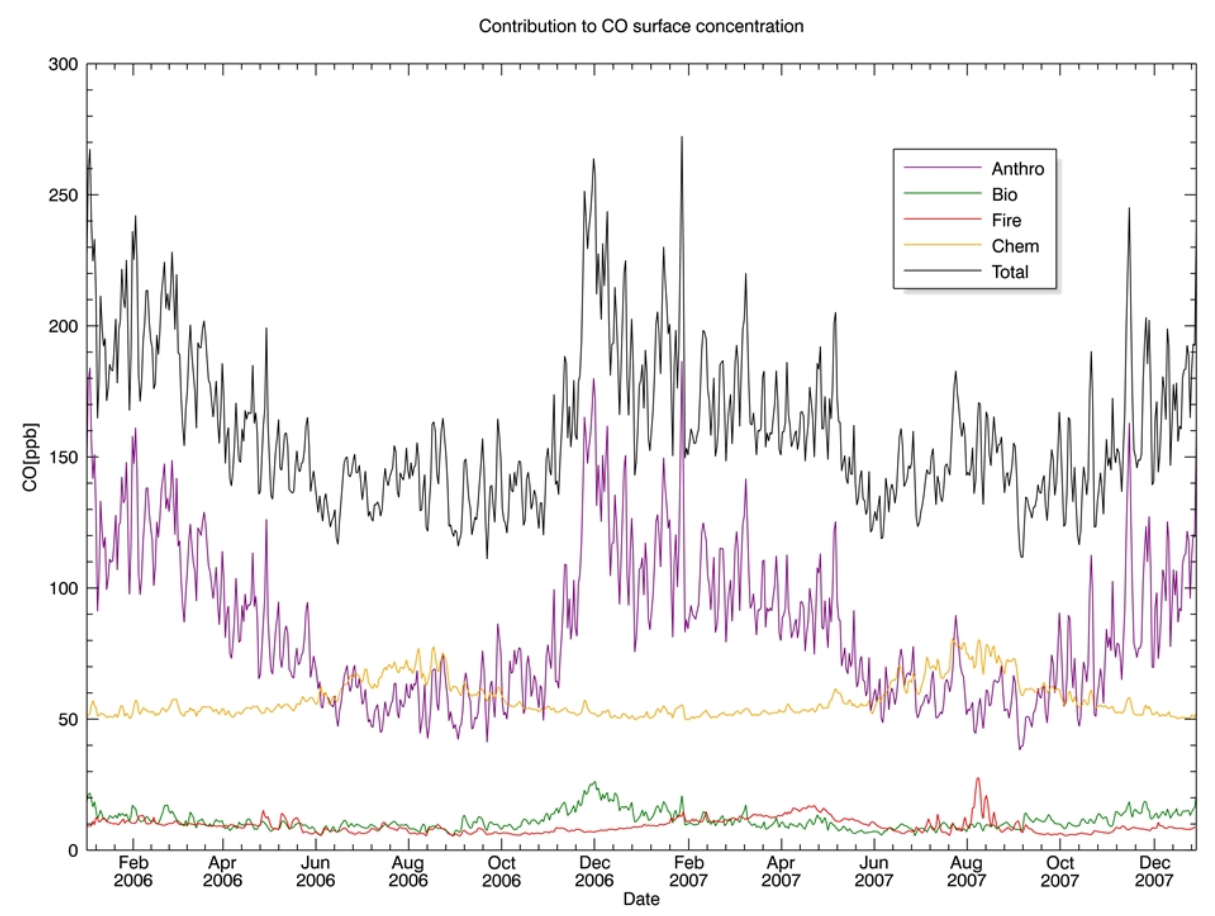

Fig. 10. CO contributed from each source type and total CO (black) as simulated by MOZART for 2006-2007. Each source represents the global contribution of a specific type. Anthropogenic sources (purple) are the main contributors to the total CO and have similar seasonal cycle as the total $\mathrm{CO}$ and large daily variability. Chemically produced $\mathrm{CO}$ (orange) have an opposite seasonal cycle (high over summer) and relatively small daily variability. Biogenic (green) and fires (red) have small daily variability.

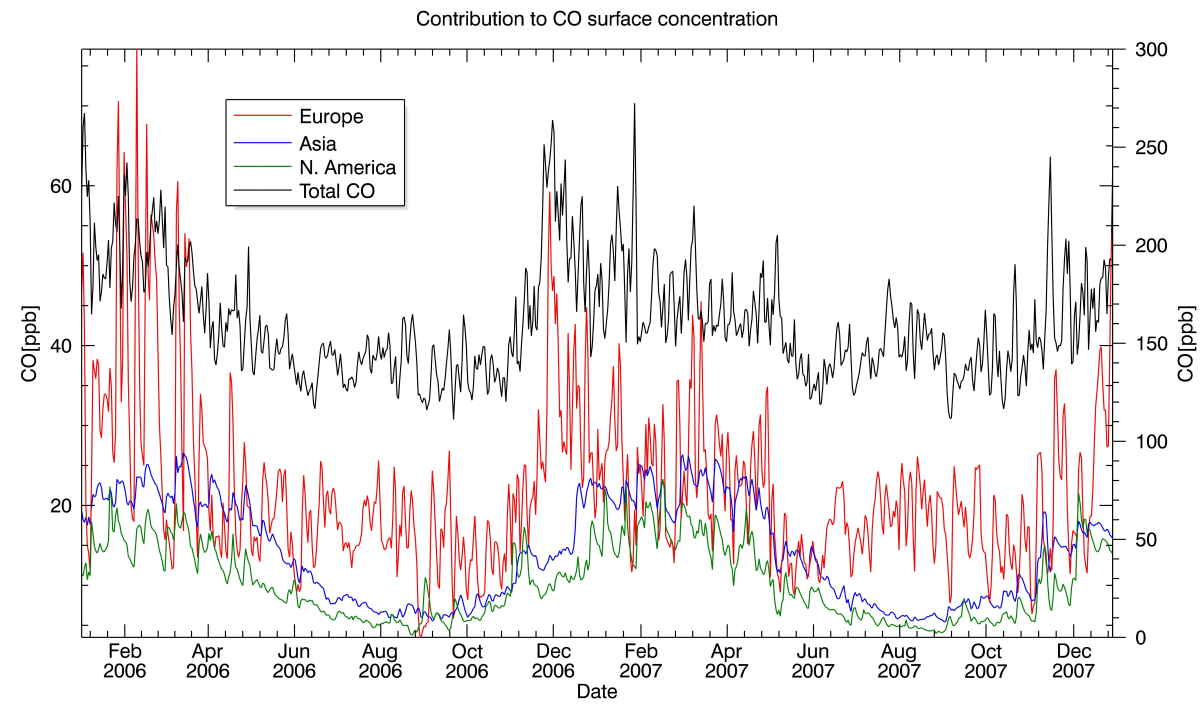

Fig. 11. The contribution of CO anthropogenic sources for each continent for 2006-2007. During Summer: European sources are dominant, with high daily variation. CO from Asia and North America has a small contribution and very small daily variability.

concentration in summer. The contribution of European emissions to local CO surface concentrations is comparable to that from local (tag 6) emissions (Fig. 12). European sources can contribute up to $80 \mathrm{ppb}$. High contributions are seen mainly during the winter months, peaking in March.
Local and European emission contributions to local $\mathrm{CO}$ concentrations is generally negatively correlated, meaning that either local or European sources are dominant (Fig. 12), except in the summer, when both local and European sources are simultaneously affecting the local $\mathrm{CO}$ concentration. A 


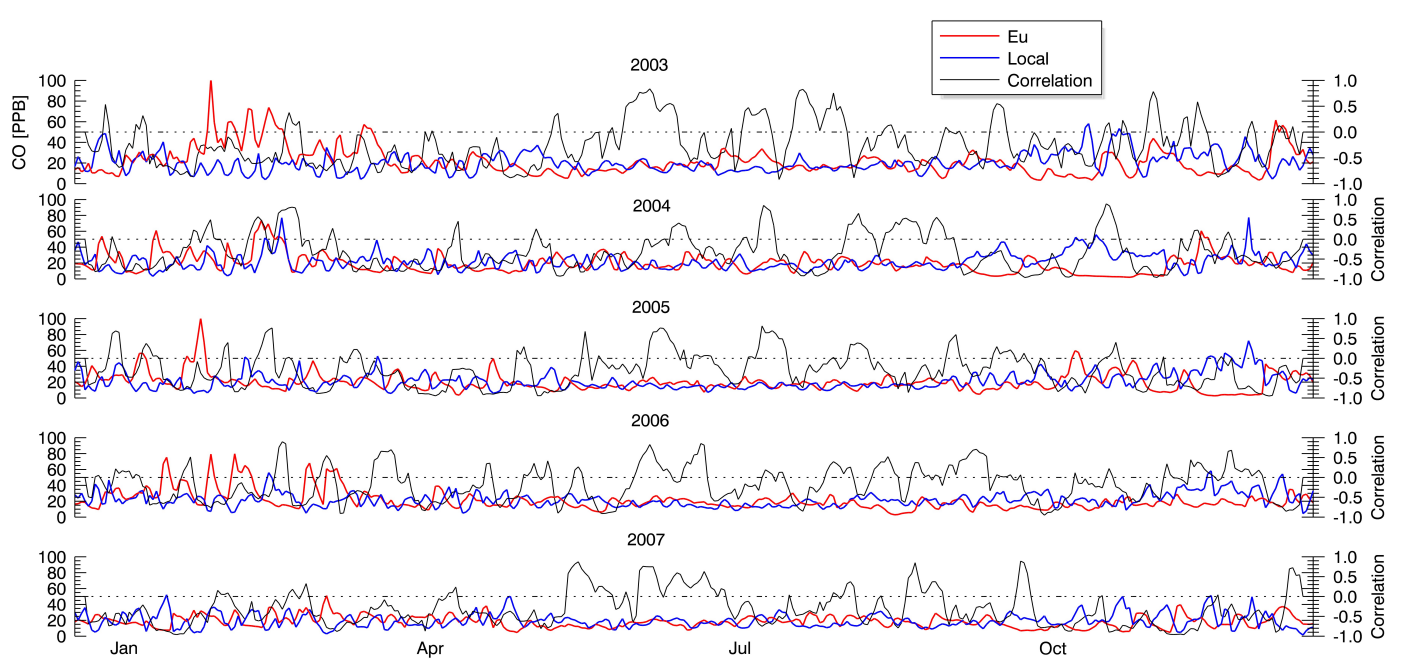

Fig. 12. A comparison between the contribution of European emissions to local CO concentrations (blue) and the contribution of local emissions to local CO concentrations (black). The European contribution is comparable to the local contribution, and they are generally negatively correlated.

possible explanation for the positive correlation in the summer is the short range of air mass transport during summer caused by the dominant synoptic system for this season, i.e., the Persian trough in its weak mode recirculating local and European emissions. European CO variability during winter is much higher than in the summer due to the stable nature of the EM summer. The European contribution is usually lower than the local contribution during autumn and higher than the local contribution during winter. The high contribution during winter can be attributed to accumulation of $\mathrm{CO}$ due to the stable atmosphere and low boundary layer over Europe and westerly winds.

The average contribution of each anthropogenic tag to the local surface concentration along with the maximum contribution is shown in Fig. 13. Anthropogenic European emissions significantly affect the EMS. All anthropogenic tags, except tag 1, contribute year-round. The highest contribution is from Turkey and Eastern Europe (tag 3). Central Europe (tag 2) and Western Europe (tags 4 and 5) are found to contribute mainly during the winter and spring. While the average tag contribution ranges between 5 and $15 \mathrm{ppb}$, extreme episodes of more than $30 \mathrm{ppb}$ were simulated (not shown here).

\section{The relative importance of European anthropogenic and BB sources to EM near surface concentrations}

Holloway et al. (2000) have conducted a detailed budget analysis for global CO distribution and found a substantial contribution of about $30 \%$ from BB sources over the EMS. The flux of European BB carbon monoxide emissions from some areas of Europe is comparable to the flux of anthropogenic $\mathrm{CO}$ emissions and may even exceed the latter dur- ing extreme BB episodes (GFED2 and POET inventories; Fig. 14). Furthermore, there is some correlation between European BB emissions and EM CO concentrations (Fig. 15). However, the European BB contribution to local surface CO concentrations in the EM is actually small. Over the five years simulated, only two cases of significant contribution were detected. The first case is at the end of April 2006, when widespread agriculture fires occurred over northern Russia (tag 5). The second case is at the end of August 2007, when huge fires occurred over Greece (tag 2). While local CO enhancement is correlated with the respective $\mathrm{BB}$ episodes over Europe, model results indicate that anthropogenic emission from tag 3 is the cause for these elevated values.

A possible explanation for the minor contribution of European $\mathrm{BB}$ to local surface $\mathrm{CO}$ concentrations in the $\mathrm{EM}$ is the change in synoptic conditions over the Mediterranean basin during summer, when most of the biomass burning occurs. The typical synoptic condition during summer over the EM is a weak or moderate Persian trough. Under these synoptic systems, air masses travel to the EM coast from the Mediterranean basin or Turkey (tag 3) with northwesterly winds at the same time, a clock-wise flow around an anticyclone located over central Mediterranean transports European pollutants southwesterly. Two high pressure systems coexist with the weak Persian through: one, over western and central Europe, the second, over Russia leading to favorable meteorological conditions for widespread forest fires. This synoptic configuration leads to a short back-trajectory from Turkey towards the EM advecting anthropogenic pollution (tag 3) but blocking BB emissions. During summer air masses tend to circulate over the EM and short back-trajectory may coexist with moderate winds. 

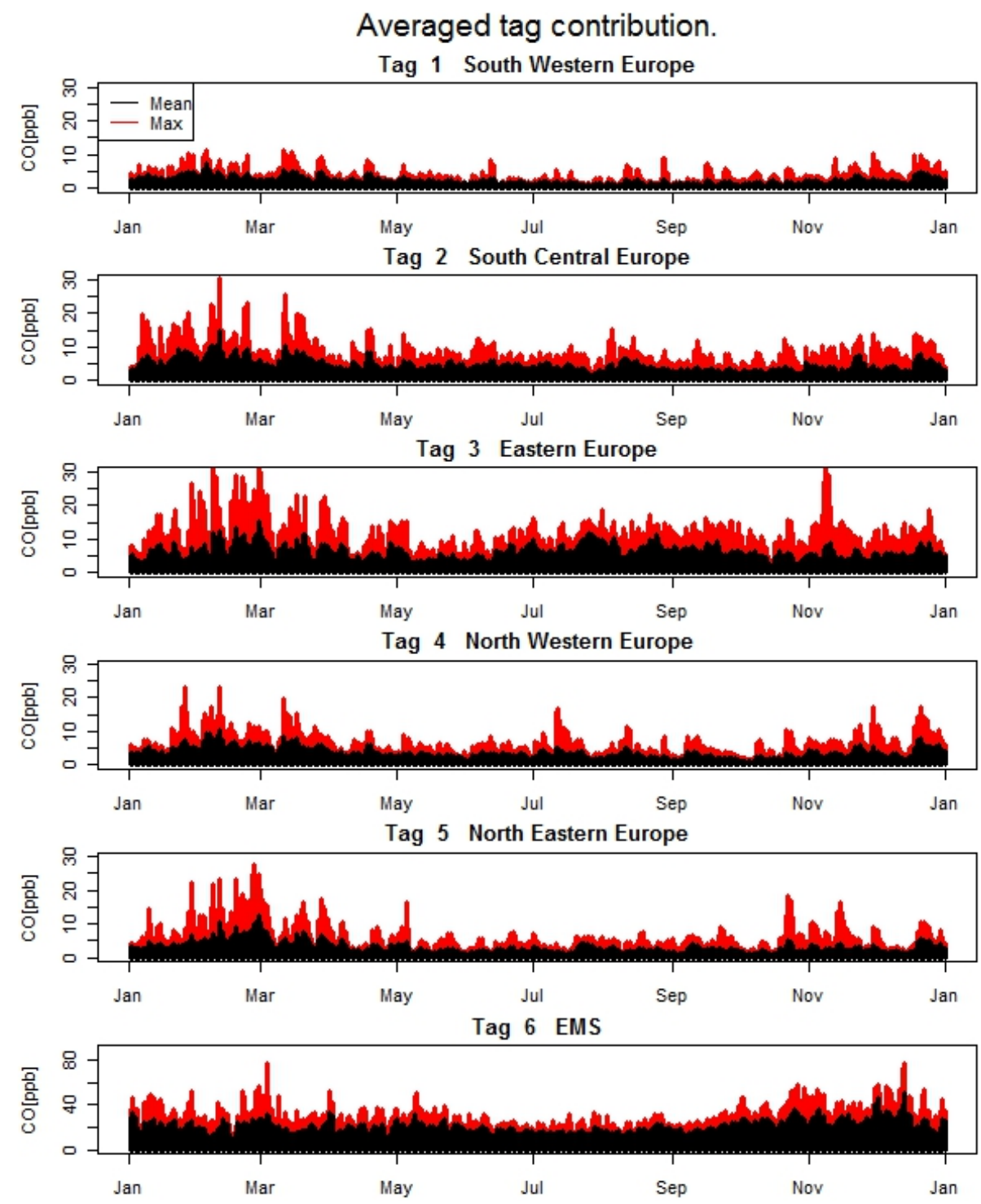

Fig. 13. Average (black) and maximum (red) tag contribution for the study period for Sde-Boker (2003-2007). Major episodes can be seen during winter months for all tags. Enhancement is for tag 3 during summer.

\section{Synoptic scale variation associated with the various sources}

There is a clear difference in the CO variability between summer 2006 and 2007 (Fig. 12). During summer 2006 low variability can be seen on both local and European sources. During summer 2007 a higher variability can be seen especially during the second part of July, where local and European contribution is uncorrelated. Transport of pollution from Europe to the EM is controlled by the wind flow resulting from a combination of synoptic systems, the one formed over $\mathrm{Eu}-$ rope in tandem with those located over the EM. Schematically this can be divided this into two cases:
1. A high pressure system over central Europe with deep Persian through over the EMS.

2. A low pressure system over northern Europe with weak or median Persian through over the EMS.

In the first case back-trajectories will tend to have longer western paths (Tags: 2,4). In the second case the backtrajectories will be shorter and north easterly paths (Tags: $3,5)$. Figure 16 shows a time series of 3 components contributing to the local concentration: the local contribution (green), western and northern contribution (Tags 2 and 4, red, hereafter western source), and north eastern contribution (Tags 3 and 5, blue, hereafter eastern sources). Figure 17 shows the 10 day composite of Sea Level Pressure (SLP) for 

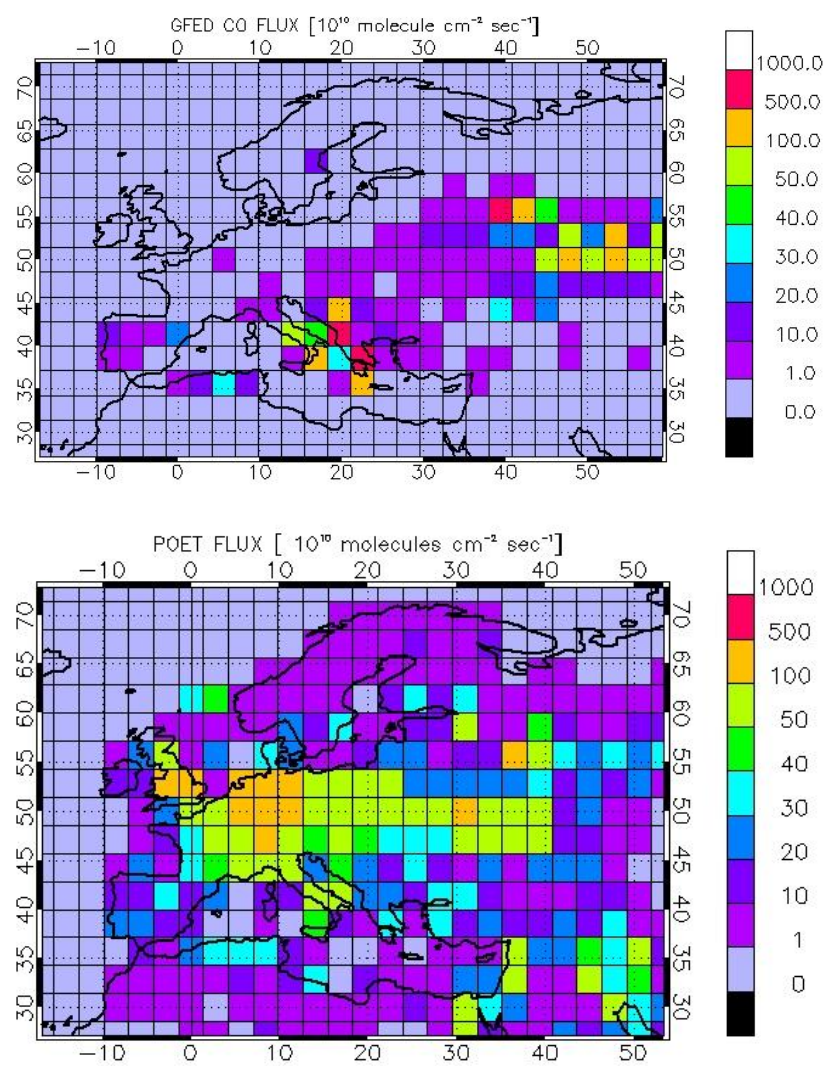

Fig. 14. Biomass burning $\mathrm{CO}$ emission fluxes $\left[10^{10}\right.$ molecules $\left.\mathrm{cm}^{-2} \mathrm{~s}^{-1}\right]$ from GFED2 for 22/08/2007 (upper panel) and fixed anthropogenic emissions from POET $\left[10^{10}\right.$ molecules $\left.\mathrm{cm}^{-2} \mathrm{~s}^{-1}\right]$ (lower panel), updated in 2005 .

the two summers. During July 2006 a low contribution can be seen from western sources and average contribution from local and eastern sources along with high pressure system over central Europe. In the beginning of August a sharp decrease can be seen in the contribution of the eastern sources along with low pressure system over central Europe at the same time there is a sharp increase in the contribution of the western sources. At the end of August there is an increase in local contribution due to intensification of the high pressure system over Western Europe. During the first two weeks of July 2007 a low contribution is seen from both eastern and western sources with an averaged contribution from local sources. A low pressure system is shown over northern Europe leading to short trajectories and higher local contribution. During the second part of July 2007 there is a decrease in western sources contribution and increase of eastern and local sources. A high pressure system can be seen all over Europe leading to back-trajectories coming from the east. During the first part of August 2007 there is a sharp decrease in local contribution and a mild increase from western sources while eastern sources show fluctuations. The high pressure system is shifting westward leading to a deep Per-

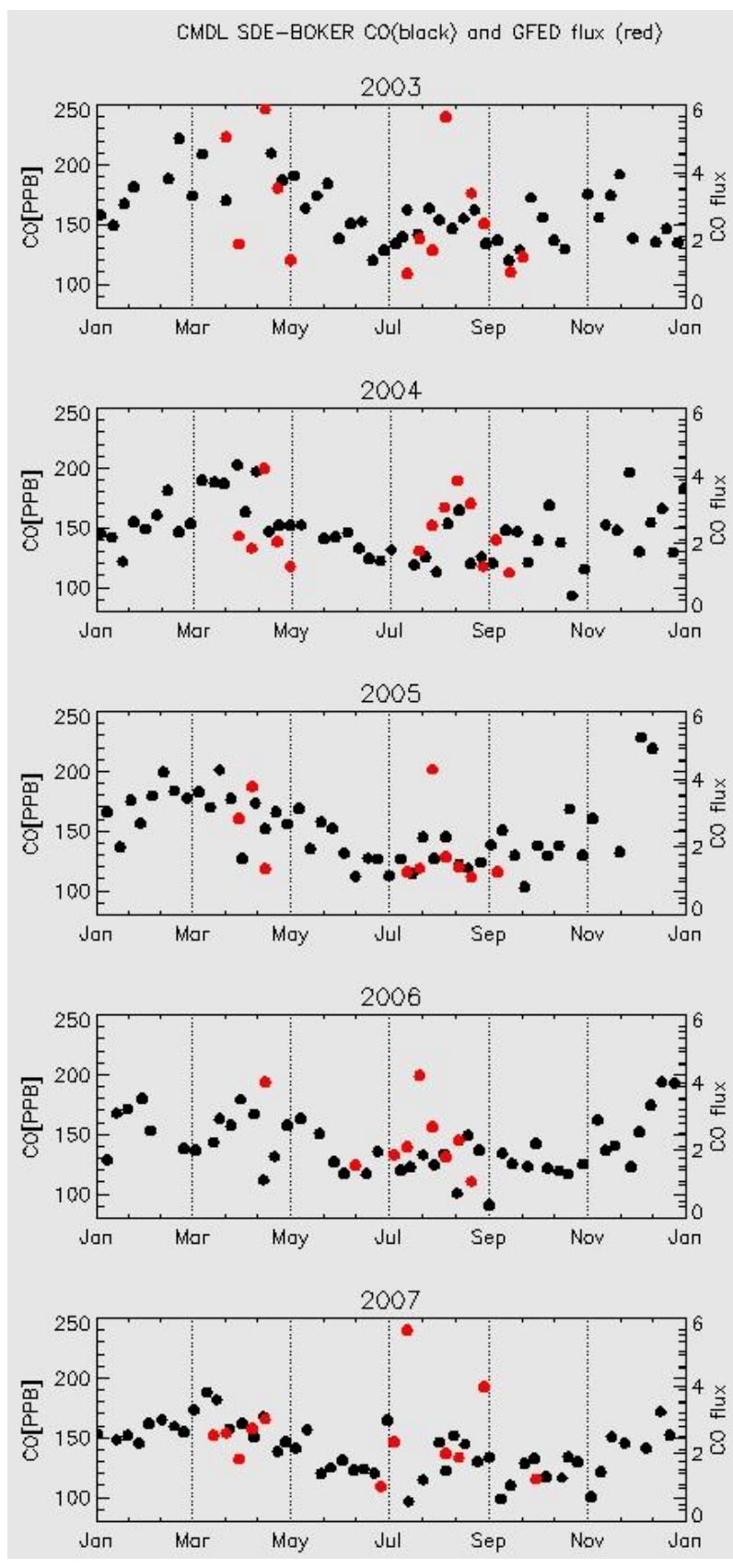

Fig. 15. Local CO surface concentration obtained from NOAA/GMD at Sde-Boker (black circles) and European BB emission fluxes $\left[10^{13}\right.$ molecule $\left.\mathrm{cm}^{-2} \mathrm{~s}^{-1}\right]$ calculated from GFED v2 (red circles). Local CO enhancement is synchronized with BB fluxes.

sian thought, a more ventilated boundary layer over Israel and trajectories coming from north Western Europe. At the second half of August 2007 a strong increase is seen in local contribution and a decrease in west sources contribution. A high pressure system can be seen over most of continental Europe leading to short back-trajectories. 

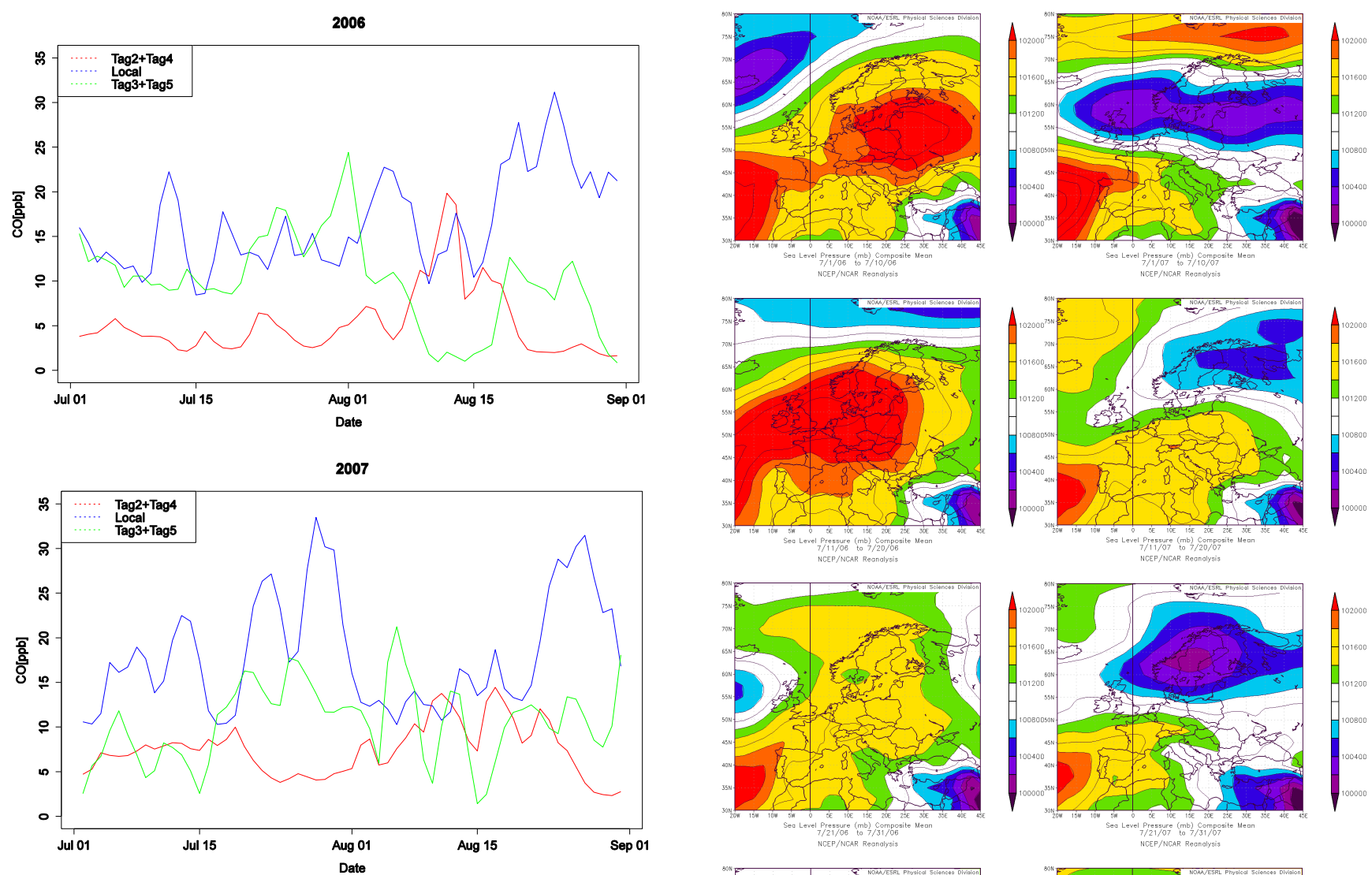

Fig. 16. The contribution of various sources to local concentration during July-August 2006 (upper panel) and 2007 (lower panel).

\section{Summary and conclusions}

This paper represents the first attempt to quantify the contribution of various European CO sources to EMS surface concentration.

The chemical transport model MOZART-4 was used to locate and quantify the impact of European $\mathrm{CO}$ emissions on $\mathrm{CO}$ surface concentrations in the EMS and particularly in Southern Israel. Model results were compared against MOPITT retrievals and ground monitoring station data and found to agree well on monthly basis and weekly basis during summer. The model was unable to reproduce the synoptic scale variation except for summer months (July-September). Selected transport events were analyzed and explained.

Our main conclusions are:

1. The CO concentration over the EMS can be described by 3 main components: anthropogenic $\mathrm{CO}$ sources seasonal cycle, the $\mathrm{CO}$ from hydrocarbon oxidation $(\mathrm{COhc})$ seasonal cycle and synoptic scale variations.

2. Anthropogenic European $\mathrm{CO}$ emissions can contribute up to $90 \mathrm{ppb}(50 \%)$ of the surface $\mathrm{CO}$ concentration in
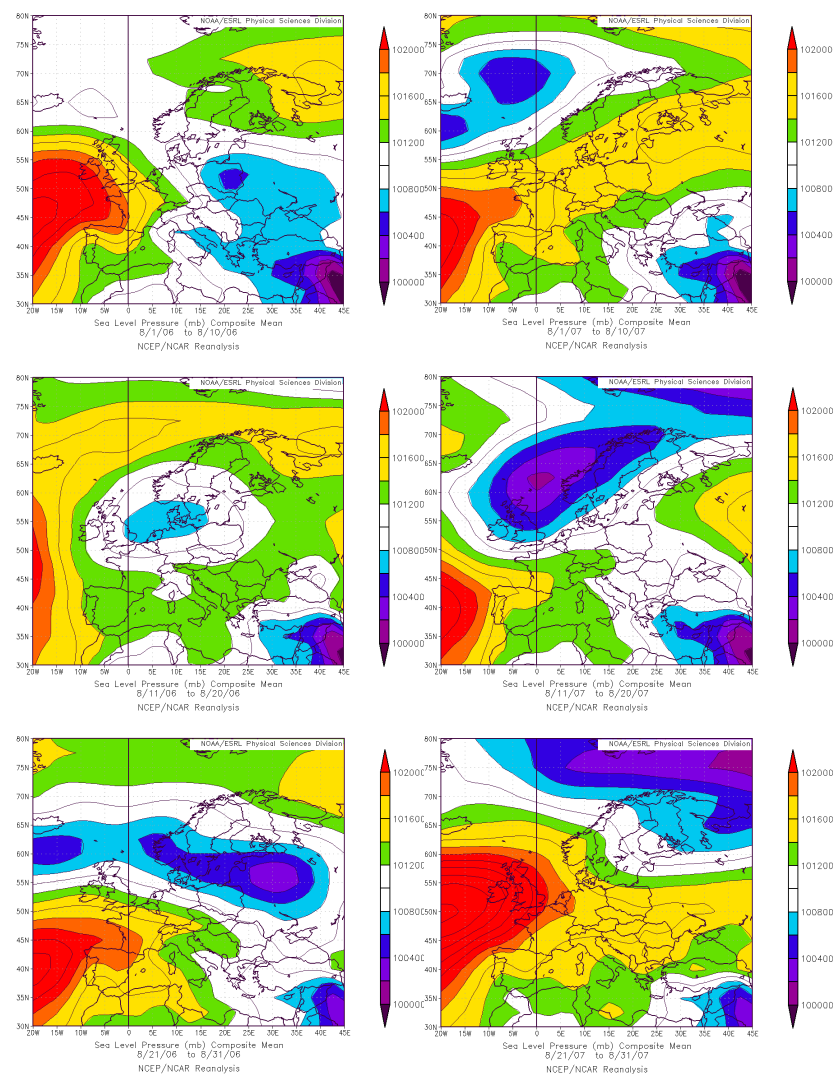

Fig. 17. 10 days SLP composite for July-August 2006 (left panel) and 2007 (right panel). 
the EM and are comparable in order to the contribution of local CO emissions.

3. The anthropogenic $\mathrm{CO}$ sources with the highest contribution to EM CO concentrations are from Turkey and Eastern Europe. Emissions from Eastern Europe contribute throughout the year to EM CO concentrations with the exception of late spring and autumn. Emissions from Central Europe mainly contribute during the winter months with a smaller contribution during summer and autumn.

4. In-situ measurements as well as modeled CO; indicate a small enhancement of $\mathrm{CO}$ concentrations in the EM during August, as opposed to the expected minima during this month. This enhancement is attributed to typical summer synoptic conditions rather than emission enhancement (such as European BB). This enhancement is not seen by remotely sensed measurements.

5. COhc contributes significantly to the local CO concentration. Cohc enhancement during summer months is probably the reason for the anomalous high $\mathrm{CO}$ in $\mathrm{Au}-$ gust.

6. European BB contribution to EM surface concentration is minimal. Typical synoptic summer conditions lead to north westerly winds over the EM, advecting CO from Turkey (tag 3). At the same time, a clock-wise flow around an anticyclone located over Western and Central Europe transports European BB south westerly.

7. CO synoptic scale variation at the receptor can be explained by the synoptic pressure systems both over the source and at the receptor area. For the EMS, a High pressure spread over entire Europe will lead to short back-trajectories and a high local contribution, while a low pressure over Europe will lead to long westerly trajectories with contribution from west sources. A high pressure system over central Europe will lead to easterly back-trajectories with higher contribution from east sources.

Acknowledgements. We acknowledge the work of the NOAA GMD group and Weizmann institute of science in making in situ measurements. The authors gratefully acknowledge the NOAA Air Resources Laboratory (ARL) for the provision of the HYSPLIT transport and dispersion model. The HUJI work was partially supported by the Ring Foundation. The National Center for Atmospheric Research is sponsored by the National Science Foundation.

Edited by: M. Kanakidou

\section{References}

Alpert, P., Osetinsky, I., Ziv, B., and Shafir, H.: Semi-objective classification for daily synoptic systems: Application to the eastern Mediterranean climate change, INT J CLIMATOL, 24, 10011011, doi:10.1002/joc.1036, 2004.

Astitha, M., Kallos, G., and Katsafados, P.: Air pollution modeling in the Mediterranean Region: Analysis and forecasting of episodes, Atmospheric Research, Volume 89, Issue 4, Air Quality: Aerosols, Dust Storms, Photochemical Pollutants, 3rd International Symposium on Air Quality Management at Urban, Regional, and Global Scales (AQM2005), September 2008, 358-364, ISSN 0169-8095, doi:10.1016/j.atmosres.2008.03.006, 2007.

Bian, H., Chin, M., Kawa, S. R., Duncan, B., Arellano, A. and Kasibhatla, P.: Sensitivity of global CO simulations to uncertainties in biomass burning sources, J. Geophys. Res., 112, D23308, doi:10.1029/2006JD008376, 2007.

Chen, Y., Li, Q., Randerson, J. T., Lyons, E. A., Kahn, R. A., Nelson, D. L., and Diner, D. J.: The sensitivity of CO and aerosol transport to the temporal and vertical distribution of North American boreal fire emissions, Atmos. Chem. Phys., 9, 6559-6580, doi:10.5194/acp-9-6559-2009, 2009.

Dayan, U. and Graber, M.: Analysis of Synoptic Conditions in the Eastern Mediterranean that Led to Elevated Air Pollution Concentrations in Israel. Proceedings of the International 12th Scientific Conference of the Israel Ecological Society, The Hebrew University of Jerusalem, Israel, 12-13 May 1981, 383-397, 1981.

Dayan, U. and Lamb, D.: Influences of atmospheric circulation on the variability of wet sulfate deposition, Int. J. Climatol., 28, 1315-1324, doi:10.1002/joc.1648, 2008.

Dayan, U. and Levy, I.: Relationship between Synoptic-scale Atmospheric Circulation and Ozone Concentrations over Israel. J. Geophys. Res., 107, 4813, doi:2002JD002147, 2002.

Dayan, U. and Levy, I.: The influence of seasonal meteorological conditions and atmospheric circulation types on $\mathrm{PM}_{10}$ and visibility in Tel-Aviv, Israel, J Appl. Meteorol., 44, 606-619, 2005.

Deeter, M. N., Emmons, L. K., Francis, G. L., Edwards, D. P. Gille, J. C., Warner, J. X., Khattatov, B., Ziskin, D., Lamarque, J. F., Ho, S. P., Yudin, V., Attie, J. L., Packman, D., Chen, J., Mao, D., and Drummond, J. R.: Operational carbon monoxide retrieval algorithm and selected results for the MOPITT instrument, J. Geophys. Res.-Atmos., 108, 4399-4410, doi:10.1029/2002jd003186, 2003.

Deeter, M. N., Emmons, L. K., Edwards, D. P., Gille, J. C., and Drummond, J. R.: Vertical resolution and information content of co profiles retrieved by MOPITT, Geophys. Res. Lett., 31, L15112, doi:10.1029/2004g1020235, 2004.

Deeter, M. N., Edwards, D. P., Gille, J. C., Emmons, L. K., Francis, G., Ho, S.-P., Mao, D., Masters, D., Worden, H., Drummond, J. R., and Novelli, P. C.: The MOPITT Version 4 CO Product: Algorithm Enhancements, Validation, and Long-Term Stability, J. Geophys. Res., 115, D07306, doi:10.1029/2009JD013005, 2010.

Draxler, R. R. and Rolph, G. D.: HYSPLIT (HYbrid Single-Particle Lagrangian Integrated Trajectory) Model access via NOAA ARL READY Website http://gus.arlhq.noaa.gov/ready/open/hysplit4. html, NOAA Air Resources Laboratory, Silver Spring, MD, USA, 2003. 
Duncan, B. N. and Bey, I: A modeling study of the export pathways of pollution from Europe: Seasonal and interannual variations (1987-1997), J. Geophys. Res.-Atmos., 109, D08301, doi:10.1029/2003JD004079, 2004.

Edwards, D. P., Emmons, L. K., Hauglustaine, D. A., Chu, D. A., Gille, J. C., Kaufman, Y. J., Petron, G., Yurganov, L. N., Giglio, L., Deeter, M. N., Yudin, V., Ziskin, D. C., Warner, J., Lamarque, J. F., Francis, G. L., Ho, S. P., Mao, D., Chen, J., Grechko, E. I., and Drummond, J. R.: Observations of carbon monoxide and aerosols from the terra satellite: Northern hemisphere variability, J. Geophys. Res.-Atmos., 109, D24202, doi:10.1029/2004jd004727, 2004.

Emmons, L. K., Edwards, D. P., Deeter, M. N., Gille, J. C., Campos, T., Nedelec, P., Novelli, P.,and Sachse, G.: Measurements of Pollution In The Troposphere (MOPITT) validation through 2006, Atmos. Chem. Phys., 9, 1795-1803, doi:10.5194/acp-91795-2009, 2009.

Emmons, L. K., Walters, S., Hess, P. G., Lamarque, J.-F., Pfister, G. G., Fillmore, D., Granier, C., Guenther, A., Kinnison, D., Laepple, T., Orlando, J., Tie, X., Tyndall, G., Wiedinmyer, C., Baughcum, S. L., and Kloster, S.: Description and evaluation of the Model for Ozone and Related chemical Tracers, version 4 (MOZART-4), Geosci. Model Dev., 3, 43-67, doi:10.5194/gmd3-43-2010, 2010.

Erel, Y., Kalderon-Asael, B., Dayan, U., and Sandler, A.: European atmospheric pollution imported by cooler air masses to the eastern mediterranean during the summer, Environ. Sci. Technol., 41, 5198-5203, doi:10.1021/es062247n, 2007.

Holloway, T., Levy II, H., and Kasibhatla, P.: Global distribution of carbon monoxide, J. Geophys. Res., 105, 12123-12147, 2000.

Giglio, L., Descloitres, J., Justice, C. O., and Kaufman, Y.: An enhanced contextual fire detection algorithm for MODIS, Remote Sens. Environ., 87, 273-282, 2003.

Granier, C., Lamarque, J. F., Mieville, A., Muller, J. F., Olivier, J., Orlando, J., Peters, J., Petron, G., Tyndall, G., and Wallens, S.: POET, a database of surface emissions of ozone precursors, available online at: http://www.aero.jussieu.fr/projet/ACCENT/ POET.php, 2005.

Kallos, G., Astitha, M., Katsafados, P., and Spyrou, C.: Long-range transport of anthropogenically and naturally produced particulate matter in the Mediterranean and North Atlantic: Current state of knowledge, J. Appl. Meteorol., 46, 1230-1251, 2007.

Kalnay, E., Kanamitsu, M., Kistler, R., Collins, W., Deaven, D., Gandin, L., Iredell, M., Saha, S., White, G., Woollen, J., Zhu, Y., Chelliah, M., Ebisuzaki, W., Higgins, W., Janowiak, J., Mo, K. C., Ropelewski, C., Wang, J., Leetmaa, A., Reynolds, R., Jenne, R., and Joseph, D.: The ncep/ncar 40-year reanalysis project, B. Am. Meteorol. Soc., 77, 437-471, 1996.

Lelieveld, J., Berresheim, H., Borrmann, S., Crutzen, P. J., Dentener, F. J., Fischer, H., Feichter, J., Flatau, P. J., Heland, J., Holzinger, R., Korrmann, R., Lawrence, M. G., Levin, Z., Markowicz, K. M., Mihalopoulos, N., Minikin, A., Ramanathan, V., de Reus, M., Roelofs, G. J., Scheeren, H. A., Sciare, J., Schlager, H., Schultz, M., Siegmund, P., Steil, B., Stephanou, E. G., Stier, P., Traub, M., Warneke, C., Williams, J., and Ziereis, H.: Global air pollution crossroads over the mediterranean, Science, 298, 794-799, 2002.
Luria, M., Peleg, M., Sharf, G., TovAlper, D. S., Spitz, N., BenAmi, Y., Gawii, Z., Lifschitz, B., Yitzchaki, A., and Seter, I.: Atmospheric sulfur over the east mediterranean region, J. Geophys. Res.-Atmos., 101, 25917-25930, 1996.

Meszaros, T., Haszpra, L., and Gelencser, A., Tracking changes in carbon monoxide budget over Europe between 1995 and 2000, Atmos. Environ., 39, 7297-7306, 2005.

Novelli, P. C., Steele, L. P., and Tans, P. P.: Mixing ratios of carbon-monoxide in the troposphere, J. Geophys. Res.-Atmos., 97, 20731-20750, 1992.

Novelli, P. C. and Masarie, K. A,:, Atmospheric Carbon Monoxide Dry Air Mole Fractions from the NOAA ESRL Carbon Cycle Cooperative Global Air Sampling Network, 1988-2009, Version: 2010-07-14, Path: ftp://ftp.cmdl.noaa.gov/ccg/co/flask/ event/, 2010.

Park, M., Randel, W. J., Emmons, L. K., and Livesey, N. J.: Transport pathways of carbon monoxide in the Asian summer monsoon diagnosed from Model of Ozone and Related Tracers (MOZART), J. Geophys. Res., 114, D08303, doi:10.1029/2008JD010621, 2009.

Pfister, G., Petron, G., Emmons, L. K., Gille, J. C., Edwards, D. P., Lamarque, J. F., Attie, J. L., Granier, C., Novelli, P. C.: Evaluation of CO Simulations and the Analysis of the CO Budget for Europe, J. Geophys. Res., 109, D19304, doi:10.1029/2004JD004691, 2004.

Ranmar, D. O., Matveev, V., Dayan, U., Peleg, M., Kaplan, J., Gertler, A. W., Luria, M., Kallos, G., Katsafados, P., and Mahrer, Y.: Impact of coastal transportation emissions on inland air pollution over israel: Utilizing numerical simulations, airborne measurements, and synoptic analyses, J. Geophys. Res.-Atmos., 107, 4331-4344, doi:10.1029/2001jd000808, 2002.

Sanderson, M., Collins, W., Derwent, R., and Johnson, C.: Simulation of global hydrogen levels using a lagrangian three dimensional model, J. Atmos. Chem., 46, 15-28, 2003.

Stohl, A., Eckhardt, S., Forster, C., James, P., and Spichtinger, N.: On the pathways and timescales of intercontinental air pollution transport, J. Geophys. Res., 107, 4684, doi:10.1029/2001JD001396, 2002.

Wanger, A., Peleg, M., Sharf, G., Mahrer, Y., Dayan, U., Kallos, U. G., Kotroni, V., Lagouvardos, K., Varinou, M., Papadopoulos, A., and Luria, M.: Some observational and modeling evidence of long range transport of air pollutants from Europe towards the Israeli coast, J. Geophys. Res., 105, 7177-7186, 2000.

Worden, H. M., Deeter, M. N., Edwards, D. P., Gille, J. C., Drummond, J. R., and Nédélec, P.: Observations of near surface carbon monoxide from space using MOPITT multispectral retrievals, J. Geophys. Res., 115, D18314, doi:10.1029/2010JD014242, 2010. 